Article

\title{
Antiviral Effect of Lithium Chloride and Diammonium Glycyrrhizinate on Porcine Deltacoronavirus In Vitro
}

\author{
Xiaofeng Zhai, Shilei Wang, Mengyan Zhu, Wei He, Zhongzhou Pan and Shuo Su * \\ MOE International Joint Collaborative Research Laboratory for Animal Health \& Food Safety, Jiangsu \\ Engineering Laboratory of Animal Immunology, Institute of Immunology, College of Veterinary Medicine, \\ Nanjing Agricultural University, Nanjing 210095, China \\ * Correspondence: shuosu@njau.edu.cn
}

Received: 25 June 2019; Accepted: 3 September 2019; Published: 9 September 2019

\begin{abstract}
Porcine deltacoronavirus (PDCoV) is an emerging global swine virus that has a propensity for interspecies transmission. It was identified in Hong Kong in 2012. Given that neither specific antiviral drugs nor vaccines are available for newly emerging porcine deltacoronavirus, searching for effective antiviral drugs is a high priority. In this study, lithium chloride $(\mathrm{LiCl})$ and diammonium glycyrrhizinate (DG), which are host-acting antivirals (HAAs), were tested against PDCoV. We found that $\mathrm{LiCl}$ and DG inhibited PDCoV replication in LLC-PK1 cells in a dose-dependent manner. The antiviral effects of $\mathrm{LiCl}$ and DG occurred at the early stage of PDCoV replication, and DG also inhibited virus attachment to the cells. Moreover, both drugs inhibited PDCoV-induced apoptosis in LLC-PK1 cells. This study suggests $\mathrm{LiCl}$ and DG as new drugs for the treatment of PDCoV infection.
\end{abstract}

Keywords: PDCoV; lithium chloride; diammonium glycyrrhizinate; apoptosis

\section{Introduction}

PDCoV, first discovered in Hong Kong in 2012, broke out in the United States in early 2014 and then spread to China, Thailand, and Canada. As a novel coronavirus, PDCoV can cause severe diarrhea and vomiting, with high mortality in piglets, which can lead to serious economic loss in the swine industry [1-3]. Coronaviruses (CoVs) are enveloped positive-stranded RNA viruses that are classified into four genera including Alpha, Beta, Gamma, and Deltacoronavirus. CoVs are prone to interspecies transmission [4]. In particular, Betacoronaviruses include SARS-CoV and MERS-CoV, which can cause lethal respiratory infections in humans and are notable examples of interspecies transmission $[5,6]$. Cross-species transmission, facilitated by the widespread prevalence of $\mathrm{CoV}$ in mammals and birds, and genetic diversity, driven by high mutation rates and high frequency of recombination, increase the chance of successful adaptation to a new host [7].

PDCoV, belonging to the genus Deltacoronavirus and the family Coronaviridae within the order Nidovirales, is a recently discovered $\mathrm{CoV}$ of unknown origin, which has a wide host range, including wild birds, swine, and other mammals [8,9]. The PDCoV genome is approximately $25 \mathrm{~kb}$ and has seven open reading frames, i.e., open reading frame $1 \mathrm{a} / 1 \mathrm{~b}(\mathrm{ORF1a} / 1 \mathrm{~b})$, spike (S), envelope (E), membrane (M), nucleocapsid (N), NS6, and NS7. As an emerging swine enteropathogenic coronavirus, PDCoV has strong pathogenicity and can cause watery diarrhea, vomiting, and high mortality in piglets, posing a potential threat to the swine husbandry. The post-infection mortality of suckling piglets can reach $30 \%$ to $40 \%$, causing serious economic losses to the pork industry [10]. PDCoV efficiently infects cells of several species, including swine, human, and chicken. Ectopic expression of porcine aminopeptidase $\mathrm{N}(\mathrm{APN})$ rendered non-susceptible cells susceptible to PDCoV infection and greatly enhance PDCoV 
infection in HeLa cells [11]. This suggests that PDCoV has the potential to spread between species and may be a threat to humans, as closely related viruses have led to outbreaks of deadly diseases such as SARS and MERS [12,13]. PDCoV global distribution in swine and its potential for transmission to multiple hosts are alarming. Pigs are the second largest livestock species and act as intermediate hosts for multiple zoonotic transmissions, emphasizing the need for studying the zoonotic potential of PDCoV and the development of antiviral drugs [14].

Given the lack of specific antiviral therapies to control PDCoV infection, searching for effective small-molecule inhibitors active against PDCoV is a high research priority. Antiviral reagents include directly acting antivirals (DAAs), which can directly act on viral components (proteins or genomes), and host-acting antivirals (HAAs), which can act on hosts [15-17]. Although DAAs are more virus-specific, viruses quickly develop resistance [18]. Antiviral methods based on host cellular mechanisms have potential advantages in reducing virus drug resistance and dealing with viral emergencies. Therefore, the search and development of HAAs has aroused more and more interest. An interesting feature of HAAs is their broad-spectrum antiviral activity, which allows for immediate treatment without a lead time being required to develop a specific therapy [19]. With the emergence of new viruses threatening human health, the discovery of new functions in existing clinical drugs is often used in the screening of modern emergency therapies. Traditional broad-spectrum antiviral drugs have shown antiviral activity against many types of viruses [17]. For example, ribavirin has antiviral activity against Hantavirus [20], H1N1 influenza virus [21], Dengue virus [22], and Chikungunya virus [23]. Therefore, the discovery of new antiviral functions for existing clinical drugs is still an important strategy against PDCoV infection.

Here, the antiviral activities of $\mathrm{LiCl}$ and DG, which are both HAAs, were studied against PDCoV. $\mathrm{LiCl}$ can inhibit the replication of a variety of viruses, including Herpesvirus type 1 (HSV-1) [24], transmissible gastroenteritis virus (TGEV) [25], porcine reproductive and respiratory syndrome virus (PRRSV) [26], pseudorabies virus (PRV) [27], and porcine epidemic diarrhea virus (PEDV) [28]. LiCl can also regulate apoptosis and promote resumption of the synthesis of host proteins in infected cells $[25,26]$. Recent studies showed that $\mathrm{LiCl}$ could effectively inhibit the entry and replication of PEDV in Vero cells in a dose-dependent manner [28]. In addition, $\mathrm{LiCl}$ can inhibit early and late apoptosis induced by PEDV. PDCoV and PEDV belong to the family Coronaviridae and have similar genomic structure. However, antiviral drugs against PDCoV have not been researched. Therefore, we explored whether $\mathrm{LiCl}$ could inhibit infection by PDCoV. The licorice extract isolated from the rhizome of Glycyrrhiza uralensis has a strong antiviral activity [29]. In recent years, licorice extracts have been shown to have antiviral effects on many viruses including human immunodeficiency virus (HIV) [30], hepatitis B virus (HBV) [31], hepatitis A virus (HAV) [32], SARS-CoV [33], infectious bronchitis virus (IBV) [34], PRRSV [29], and PRV [27]. According to previous studies, DG pre-treatement inhibited PRV infection in a dose-dependent manner and reduced apoptosis [27]. Glycyrrhizin and DG have antiviral effect against SARS-CoV and IBV. Additionally, the water solubility of DG is better than that of glycyrrhizin, so we chose to verify the effect of DG on PDCoV.

Here, we report that $\mathrm{LiCl}$ and DG inhibit the replication of the PDCoV strain SD2018/10 in LLC-PK1 cells in a dose-dependent manner. The antiviral activity of LiCl mainly occurs at the early stage of viral infection, while the antiviral activity of DG mainly occurs at the stage of viral attachment. In addition, both drugs inhibited PDCoV-induced apoptosis in LLC-PK1 cells. Therefore, the potential and theoretical bases of the two drugs as therapeutic drugs for PDCoV were validated.

\section{Materials and Methods}

\subsection{Cells Culture and Reagents}

LLC-PK1 cells (porcine kidney proximaltubular epithelial cells) (ATCC ${ }^{\circledR}$ CL-101 ${ }^{\mathrm{TM}}$ ) were grown in Dulbecco's modified Eagle's medium (DMEM, Hyclone, USA) supplemented with 10\% fetal bovine serum (FBS, Gibco, Calsbad, USA) at $37^{\circ} \mathrm{C}$ in a $5 \% \mathrm{CO}_{2}$ incubator. LiCl (Sigma, St. Louis, MO, USA) 
and DG (TargetMol, Shanghai, China) were diluted in DMEM at $1 \mathrm{M}$ and $10 \mathrm{mg} / \mathrm{mL}$, respectively, and filter-sterilized.

\subsection{Virus Stocks and Titration}

The PDCoV strain SD2018/10 from our lab was used in this study. The number of infectious PDCoV particles was determined on the basis of the $50 \%$ tissue culture infectious dose $\left(\mathrm{TCID}_{50}\right)$ in LLC-PK1 cells. Briefly, the cells were seeded into 96-cell plates and grown to $100 \%$ confluence for $24 \mathrm{~h}$. Then, the cells were infected using 10-fold serial dilutions of virus samples. After incubation at $37^{\circ} \mathrm{C}$ for $2 \mathrm{~h}$, the cells were washed three times with PBS and incubated for $72 \mathrm{~h}$. Titers are reported as $\mathrm{TCID}_{50}$ calculated by the method of Reed and Muench.

\subsection{Cytotoxicity Assay}

The cytotoxicity of $\mathrm{LiCl}$ and DG was assessed in vitro using the Cell Counting Kit-8 (CCK8, $\mathrm{APE} \times \mathrm{BIO}$, Houston, TX, USA) according to the manufacturer's instructions. LLC-PK1 cells were seeded into 96-cell plates and grown to $100 \%$ confluence for $24 \mathrm{~h}$. After washing three times with PBS, the cells were treated with increasing concentrations of $\mathrm{LiCl}$ ranging from 0 to $100 \mathrm{mM}$ or DG ranging from 50 to $5000 \mu \mathrm{g} / \mathrm{mL}$. Mock-treated cells served as a control. After $36 \mathrm{~h}$, the cells were washed with PBS and incubated with $90 \mu \mathrm{L}$ DMEM and $10 \mu \mathrm{L}$ of CCK- 8 solution at $37^{\circ} \mathrm{C}$ for $2 \mathrm{~h}$. Absorbance was measured with a microplate reader (Tecan, M200 PRO, CH) at $450 \mathrm{~nm}$. Cytotoxicity was expressed according to the following formula:

$$
\text { Cytotoxicity }(\%)=\frac{(\text { Abs sample })-(\text { Abs blank })}{(\text { Abs negative control })-(\text { Abs blank })} \times 100
$$

\subsection{Antiviral Assay}

To investigate the antiviral efficacy of $\mathrm{LiCl}$ and DG against PDCoV replication, cells were infected with PDCoV (MOI 0.05) at $37^{\circ} \mathrm{C}$ for $1 \mathrm{~h}$. Unbound viruses were removed by washing with cold PBS. The cells were then incubated with $\mathrm{LiCl}(60 \mathrm{mM})$ or DG $(1250 \mu \mathrm{g} / \mathrm{mL})$ at $37^{\circ} \mathrm{C}$ for $24 \mathrm{~h}$. As a control, another set of cells were infected with the same dose of PDCoV without drug treatment. Subsequently, the antiviral efficacy was evaluated by analysis of viral RNA (vRNA) levels and viral loads.

\subsection{Analysis of the Effect of LiCl and DG on Viral Attachment}

LLC-PK1 cells were seeded into 12-cell plates and grown to $100 \%$ confluence for $24 \mathrm{~h}$. Non-toxic concentrations of $\mathrm{LiCl}(60 \mathrm{mM})$ or DG $(1250 \mu \mathrm{g} / \mathrm{mL})$ were mixed with the virus (MOI 0.05), and the mixtures were then added to the cells, followed by incubation for $1 \mathrm{~h}$ at $4{ }^{\circ} \mathrm{C}$. As a control, the cells were infected with the same dose of PDCoV without drug treatment. After washing with cold PBS, the levels of vRNA in the cells were determined by real-time qPCR.

\subsection{Analysis of the Viricidal Effect}

PDCoV (MOI 0.05) was incubated for $2 \mathrm{~h}$ at room temperature or $37^{\circ} \mathrm{C}$ in the absence or presence of $\mathrm{LiCl}(60 \mathrm{mM})$ or DG $(1250 \mu \mathrm{g} / \mathrm{mL})$ in a final volume of $1000 \mu \mathrm{L}$. After incubation, the infectious titer was determined by TCID $_{50}$ in LLC-PK1 cells.

\subsection{Analysis of the Effect of LiCl and DG on Viral Entry}

The cells were infected with PDCoV (MOI 0.05) at $4{ }^{\circ} \mathrm{C}$ for $1 \mathrm{~h}$. Unbound viruses were removed by washing with cold PBS. The cells were then incubated with $\mathrm{LiCl}(60 \mathrm{mM})$ or DG $(1250 \mu \mathrm{g} / \mathrm{mL})$ at $37^{\circ} \mathrm{C}$ for $2 \mathrm{~h}$. As a control, another set of cells were infected with the same dose of PDCoV without drug treatment. After removing the unbound viruses by washing with cold PBS (pH 3.0), the levels of vRNA in cells were determined by real-time qPCR. 


\subsection{Real-Time $q P C R$}

Total cellular RNA was extracted using the RNApure Tissue \& Cell Kit (CWBIO, Nanjing, China). The primers for PDCoV M and $\beta$-actin genes were: PDCoV-F, $5^{\prime}$-ACAATCGACCACATGGCTCCAA- $3^{\prime}$, PDCoV-R, $5^{\prime}$-CAGCTCTTGCCCATGTAGCTTCA-3',$\beta$-actin-F, $5^{\prime}$-CTCCATCATGAAGTGCGACGT- ${ }^{\prime}$, $\beta$-actin-R, $5^{\prime}$-GTGATCTCCTTCTGCATCCTGTC-3' [1]. The quantity of vRNA was determined using a LightCycler96 (Roche, Germany) and HiScript II One Step qRT-PCR SYBR Green Kit (Vazyme, Nanjing, China), according to the instructions of the manufacturer. The relative level of RNA expression was determined by the $2^{-\triangle \Delta C T}$ method. $\beta$-actin mRNA level was used as a loading control. The mean RNA level of the mock-treated group was set at $100 \%$.

\subsection{Indirect Immunofluorescence Assay (IFA)}

After infection, the cells were fixed with cold polysorbate for $30 \mathrm{~min}$ at room temperature and permeabilized with $0.2 \%$ Triton X-100 in PBS for $10 \mathrm{~min}$. After washing five times with PBS, cthe ells were incubated with rabbit anti-N antibody $(1: 500)$ at $4{ }^{\circ} \mathrm{C}$ for $12 \mathrm{~h}$. The cells were then incubated with FITC-conjugated goat anti-rabbit IgG (1:100, KPL, Colton, CA, USA) at $37^{\circ} \mathrm{C}$ for $30 \mathrm{~min}$. After washing five times with PBS, the cells were incubated with DAPI (1:1000, diluted in PBS) at room temperature for $20 \mathrm{~min}$. Fluorescence was observed under a Nikon ECLIPSE TS100 fluorescence microscope (Nikon, Tokyo, Japan).

\subsection{Analysis of Cell Apoptosis}

Apoptosis was investigated using the AnnexinV Alexa Fluor647/PI kit (FMSAV647-100) by flow cytometry. LLC-PK1 cells were detached using Accutase Cell Detachment Solution (FMS-AT 100) for $5 \mathrm{~min}$ and then centrifuged at $2000 \mathrm{rpm}$ for $5 \mathrm{~min}$. The cells were washed twice with PBS and re-suspended with $500 \mu \mathrm{L}$ of binding buffer at a concentration of $10^{6}$ cells $/ \mathrm{mL}$. Then, $5 \mu \mathrm{L}$ of AF647-conjugated AnnexinV and $10 \mu \mathrm{L}$ of PI were added to the cells, which was followed by incubation at room temperature for $15 \mathrm{~min}$ in the dark. Flow cytometry was carried out in a Becton Dickinson Accuri C6 FACSCalibur cytometer (BD Accuri C6 Plus, BD Medical Devices (Shanghai) Co., Ltd., Shanghai, China).

\subsection{Statistical Analysis}

The concentration of drugs that caused $80 \%$ cellular cytotoxicity is referred to as $\mathrm{CC}_{80}$. Experiments were performed in triplicate. Data are represented as the mean \pm standard deviation (SD). Statistical differences were determined using a paired $t$-test and a one-way ANOVA using the Prism 8.0 software (GraphPad Software,). A $p$-value $<0.05$ was selected to indicate significance.

\section{Results}

$\mathrm{LiCl}$ and DG cytotoxicity in LLC-PK1 cells. The cellular cytotoxic effect of $\mathrm{LiCl}$ and DG in LLC-PK1 cells was determined using the CCK8 kit. The structure of DG is shown in Figure 1A. The maximum $\mathrm{LiCl}$ and $\mathrm{DG}$ concentrations that resulted in a cell viability higher than $80 \%$ were $60 \mathrm{mM}$ and $1250 \mu \mathrm{g} / \mathrm{mL}$, respectively (Figure 1B,C). No differences in cell morphology compared to the mock-treated cells were observed (data not shown) at concentrations of $60 \mathrm{mM} \mathrm{LiCl}$ and $1250 \mu \mathrm{g} / \mathrm{mL}$ DG; therefore, $10-60 \mathrm{mM} \mathrm{LiCl}$ and 125-1250 $\mu \mathrm{g} / \mathrm{mL}$ DG were used in subsequent antiviral assays.

$\mathrm{LiCl}$ and DG inhibit PDCoV replication. Next, we investigated the effect of $\mathrm{LiCl}$ and DG on the replication of PDCoV in LLC-PK1 cells. PK-1 cells were infected with PDCoV at MOI 0.05 for $1 \mathrm{~h}$ and treated with $10-60 \mathrm{mM} \mathrm{LiCl}$ or $125-1250 \mu \mathrm{g} / \mathrm{mL}$ DG for $24 \mathrm{~h}$. The relative mRNA expression was detected by real-time qPCR. Treatment with $10-60 \mathrm{mM} \mathrm{LiCl}$ or $125-1250 \mu \mathrm{g} / \mathrm{mL}$ DG inhibited viral mRNA levels significantly (Figures 2A and 3A). Infectious virus loads in cell culture supernatants were determined by $\mathrm{TCID}_{50}$. We found that $10-60 \mathrm{mM} \mathrm{LiCl}$ or $125-1250 \mu \mathrm{g} / \mathrm{mL}$ DG significantly inhibited viral replication compared to mock-treated cells (Figures 2B and 3B). In IFA, the fluorescence intensity 
declined after treatment with $10-60 \mathrm{mM} \mathrm{LiCl}$ or $125-1250 \mu \mathrm{g} / \mathrm{mL}$ DG in a dose-dependent manner (Figures 2C and $3 \mathrm{C}$ ). The fluorescence intensity was quantified, showing that the number of infected cells decreased in a drug dose-dependent manner (Figures 2D and 3D). These results indicate that $\mathrm{LiCl}$ and DG inhibit PDCoV replication in a dose-dependent manner.

A
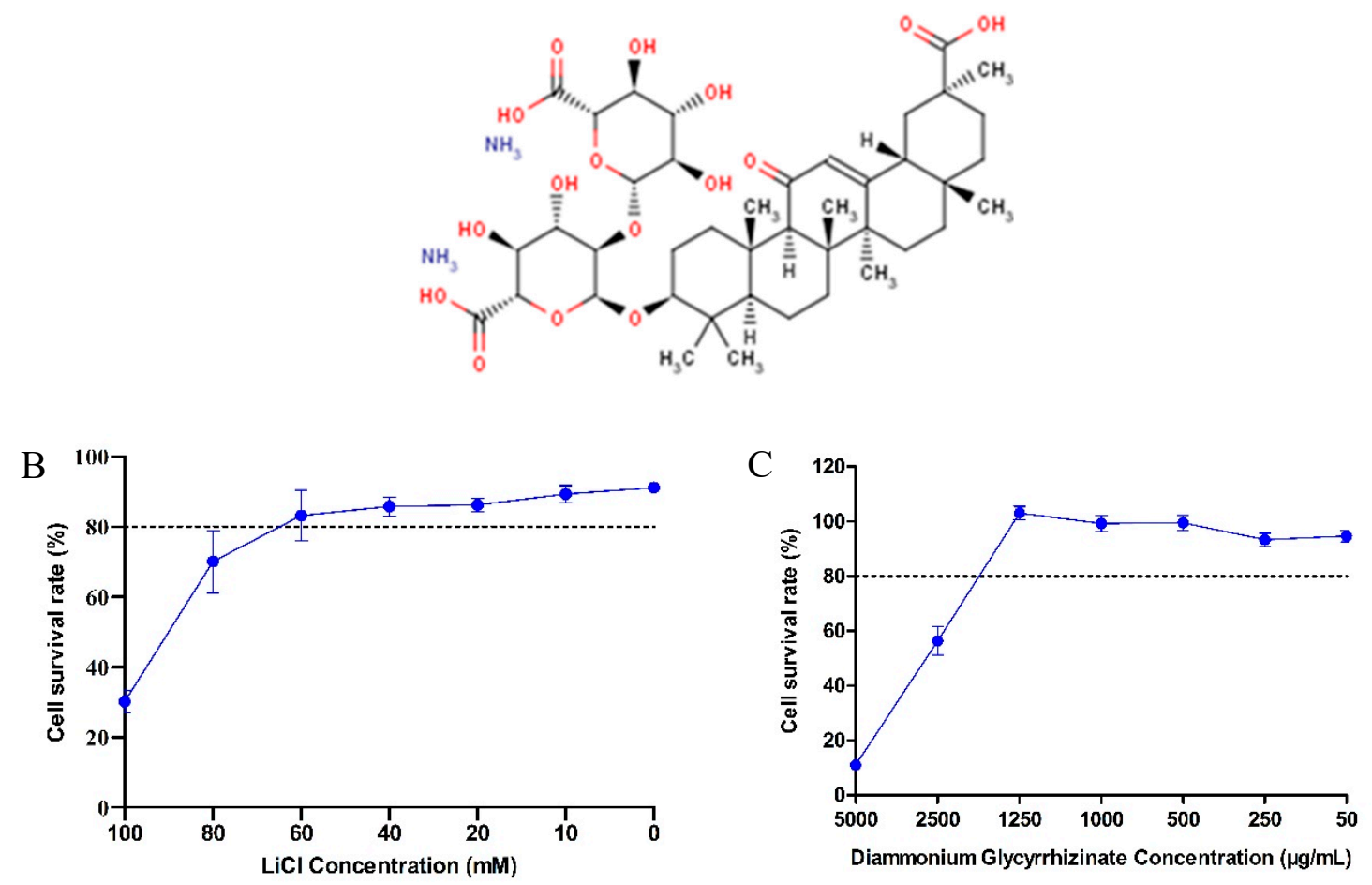

Figure 1. Cytotoxic effect of $\mathrm{LiCl}$ and DG treatment in LLC-PK1 cells. (A) Chemical structure of diammonium glycyrrhizinate (DG). Cells were treated with $0-100 \mathrm{mM} \mathrm{LiCl}$ (B) or 50-5000 $\mu \mathrm{g} / \mathrm{mL} \mathrm{DG}$ (C) for $36 \mathrm{~h}$. The relative cell viability was evaluated by the CCK-8 Kit according to the manufacturer's instructions. The data are expressed as the mean $\pm \mathrm{SD}$ of three independent experiments. The dotted line indicates the $80 \%$ cytostatic concentration $\left(\mathrm{CC}_{80}\right)$.

DG but not $\mathrm{LiCl}$ inhibits virus attachment to cells. To further explore in which step of the viral life cycle the drugs work, viral attachment and entry assays were performed in LLC-PK1 cells. There were no significant differences between mock-treated cells and cells treated with $60 \mathrm{mM} \mathrm{LiCl}$ in viral attachment or entry based on the mean relative viral mRNA levels (Figure 4A). In the entry experiments, there were no significant differences between mock-treated cells and cells treated with $1250 \mu \mathrm{g} / \mathrm{mL}$ DG in the mean relative viral mRNA levels. In viral attachment assays, DG treatment led to a significant reduction of viral mRNA levels compared to mock-treated cells (Figure 4B).

$\mathrm{LiCl}$ and DG have no viricidal effect on PDCoV virions. To understand whether $\mathrm{LiCl}$ and DG have a direct (viricidal) effect on virions, we incubated PDCoV (MOI 0.05) with $60 \mathrm{mM} \mathrm{LiCl}$ or $1250 \mu \mathrm{g} / \mathrm{mL}$ DG for $2 \mathrm{~h}$ at room temperature or $37^{\circ} \mathrm{C}$ before infection of LLC-PK1 cells. The infectious titer was determined by $\mathrm{TCID}_{50}$ at 48 hours postinfection (hpi). We found that none of the drugs directly inhibited PDCoV infectivity (Figure 5A,B).

The antiviral effects of $\mathrm{LiCl}$ and DG occur at the early stage of PDCoV replication. To further illustrate the effect of $\mathrm{LiCl}$ and DG on PDCoV infection, we performed time of addition experiments (Figure 6A). Therefore, $\mathrm{LiCl}$ or DG was added to infected LLC-PK1 cells at different times. In the ' 0 hpi' experiment, drugs and virus were added together to LLC-PK1 cells for $1 \mathrm{~h}$. The cells were then washed, and the incubation was continued in the presence of the drugs. In the other experiments, LLC-PK1 
cells were infected with PDCoV for $1 \mathrm{~h}$, the cells were then washed, and the drugs were added at 1, 3, 6, $9,12,16$, and 20 hpi. In all experiments, the cells were infected with PDCoV [ multiplicity of infection $(\mathrm{MOI})=0.05]$, and $60 \mathrm{mM} \mathrm{LiCl}$ or $1250 \mu \mathrm{g} / \mathrm{mL} \mathrm{DG}$ was added. The viral contents were significantly reduced in cells treated with $\mathrm{LiCl}$ at 0 to $16 \mathrm{~h}$, but no significant reduction was detected after $16 \mathrm{~h}$ (Figure 6B). For DG, the latest effective time point of drug treatment was $12 \mathrm{hpi}$ (Figure 6C). Therefore, we can conclude that the antiviral effects of $\mathrm{LiCl}$ and DG occur at the early stages of PDCoV replication.

A

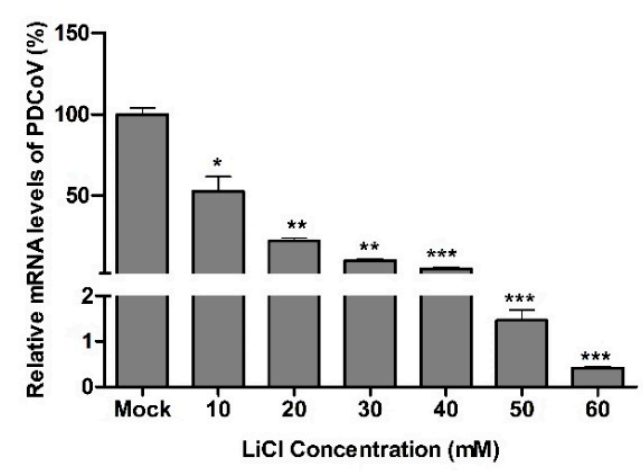

$\mathrm{C}$

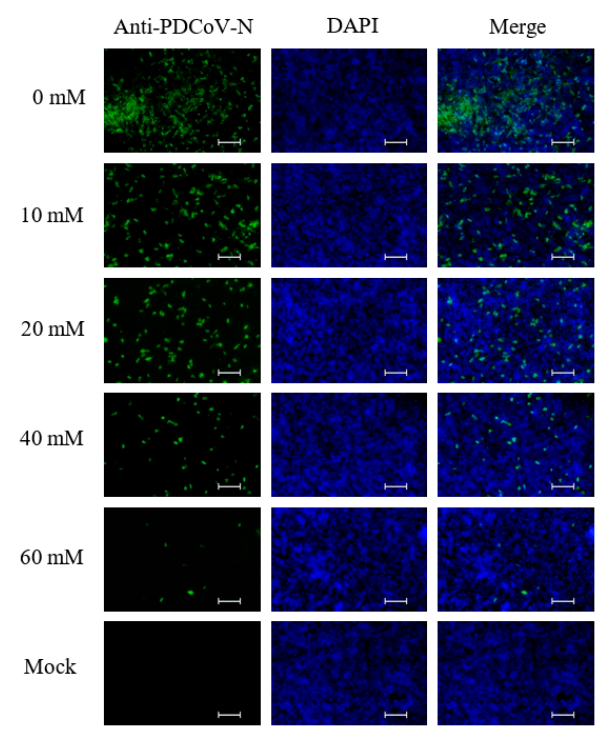

$\mathrm{B}$

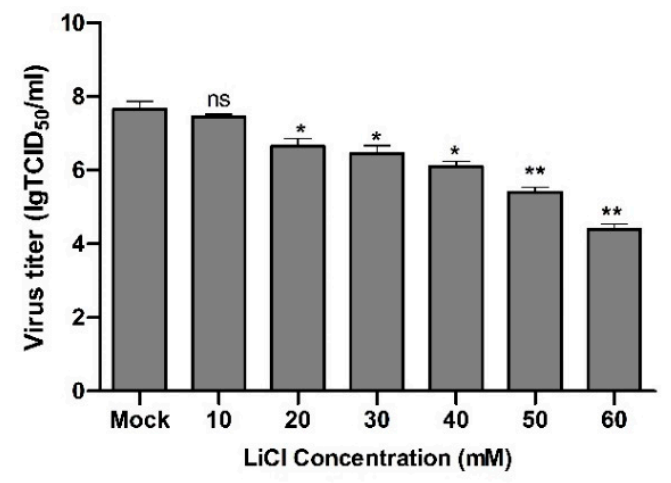

$\mathrm{D}$

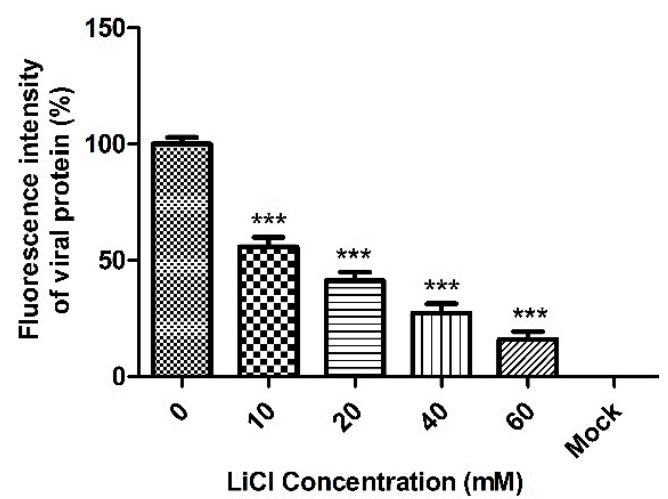

Figure 2. Antiviral effect of $\mathrm{LiCl}$ on porcine deltacoronavirus (PDCoV) replication. (A) The relative viral RNA level was determined by real-time qPCR. (B) The viral titer $\left(\log _{10} \mathrm{TCID} 50 / \mathrm{mL}\right)$ in LLC-PK1 cell lysates was calculated by the method of Reed and Muench. (C) At $24 \mathrm{~h}$ post-infection, PDCoV (MOI 0.05) replication in LLC-PK1 cells was determined by indirect immunofluorescence assay (IFA). Green fluorescence represents PDCoV replication, while blue fluorescence represents the nuclear distribution. (D) The fluorescence intensity in C was quantified with the software ImageJ. Quantification of PDCoV-infected cells from the IFA images is presented as percentage, taking $0 \mathrm{mM} \mathrm{LiCl}$ as $100 \%$. Values represent the mean $\pm \mathrm{SD}$ of three independent experiments; ns, not significant difference; ${ }^{*} p<0.05$; ${ }^{* *} p<0.01 ; * * *<0.001$. Scale bar, $250 \mu \mathrm{m}$. 


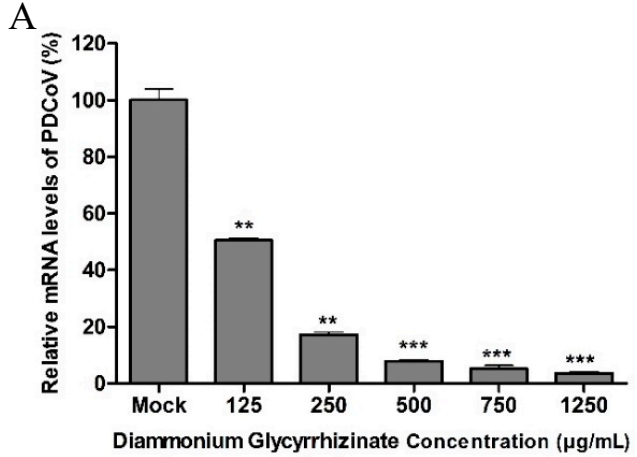

C

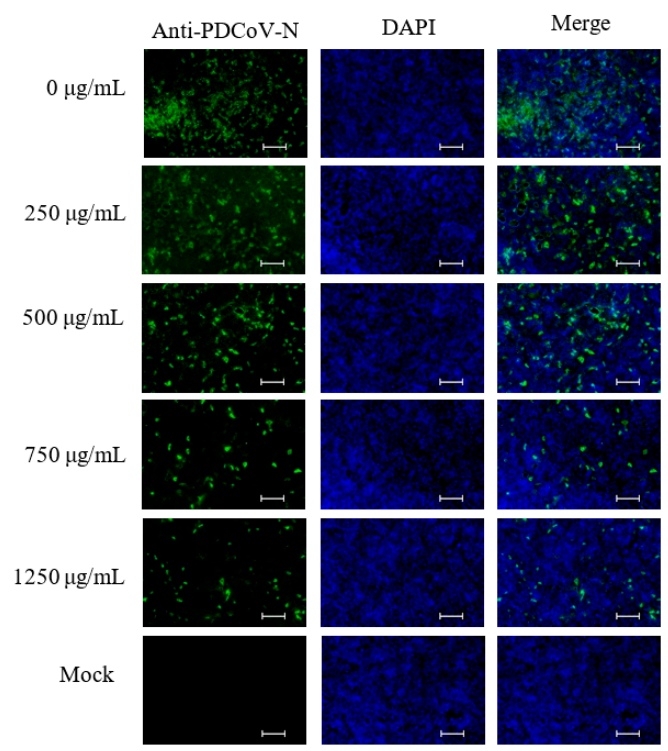

B

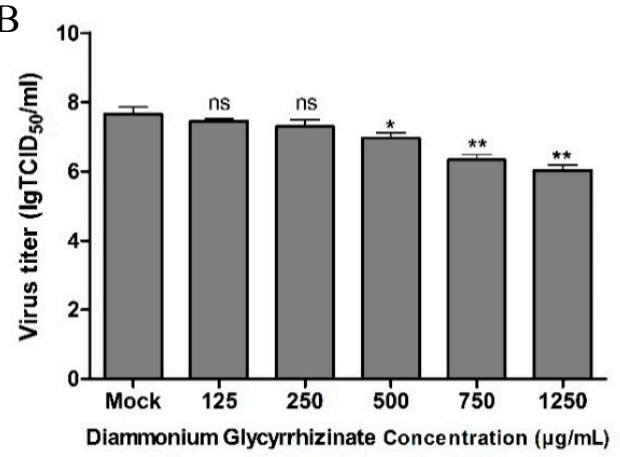

D

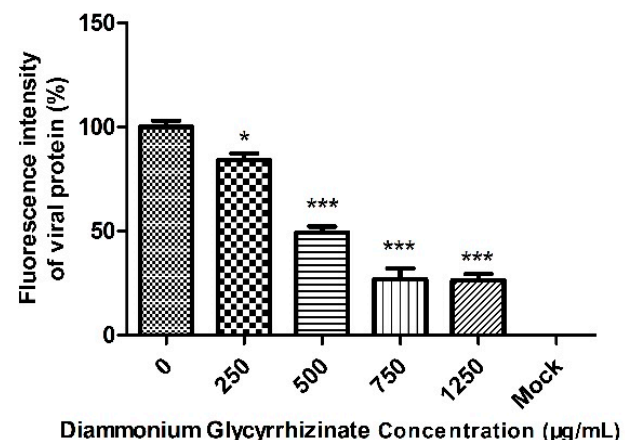

Figure 3. Antiviral effect of DG on PDCoV replication. (A) The relative viral RNA level was determined by real-time qPCR. (B). The viral titer $\left(\log _{10} \mathrm{TCID} 50 / \mathrm{mL}\right)$ in LLC-PK1 cell lysates was calculated by the method of Reed and Muench. (C) At $24 \mathrm{~h}$ post-infection, PDCoV (MOI 0.05) replication in LLC-PK1 cells was determined by IFA. Green fluorescence represents the PDCoV replication, while blue fluorescence represents the nuclear distribution. (D) The fluorescence intensity in $C$ was quantified with the software ImageJ. Quantification of PDCoV infected cells from the IFA images is presented as percentage, taking $0 \mu \mathrm{g} / \mathrm{mL}$ DG as $100 \%$. Values represent the mean \pm SD of three independent experiments; ns, not significant difference; ${ }^{*} p<0.05 ;{ }^{* *} p<0.01 ;{ }^{* * *} p<0.001$. Scale bar, $250 \mu \mathrm{m}$.
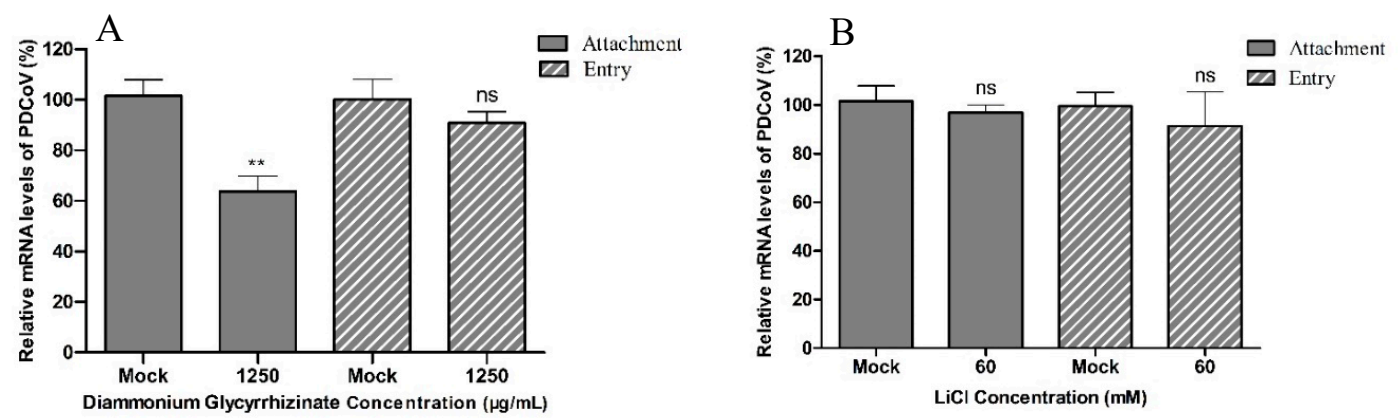

Figure 4. Effect of $\mathrm{LiCl}$ and DG on different stages of the PDCoV replication cycle. (A). The levels of vRNA in cells treated with $60 \mathrm{mM} \mathrm{LiCl}$ during viral attachment and entry were determined by real-time qPCR. (B) Same experiment as in A but using DG at $1250 \mu \mathrm{g} / \mathrm{mL}$. Values represent the mean \pm SD of three independent experiments; ns, no significant difference; ${ }^{*} p<0.05$; ${ }^{* *} p<0.01$; ${ }^{* * *} p<0.001$. 

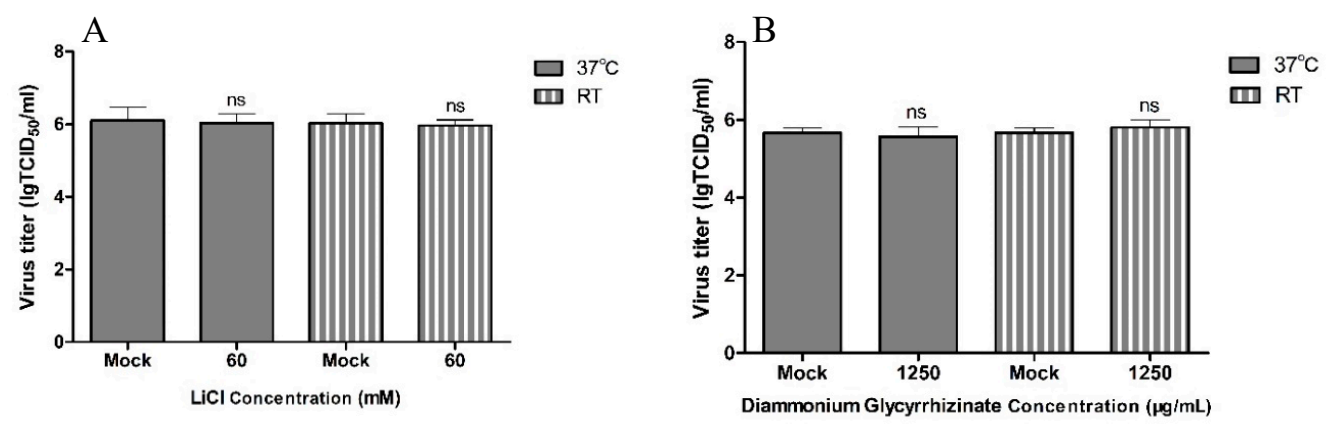

Figure 5. The viricidal effect of $\mathrm{LiCl}$ and DG on PDCoV. (A) PDCoV virions were incubated with $60 \mathrm{mM}$ $\mathrm{LiCl}$ at $37^{\circ} \mathrm{C}$ or room temperature. The viral titers $\left(\log _{10} \mathrm{TCID} 50 / \mathrm{mL}\right)$ were calculated by the method of Reed and Muench. (B) Same experiment as in A but using DG at $1250 \mu \mathrm{g} / \mathrm{mL}$. Values represent the mean \pm SD of three independent experiments, $\mathrm{ns}$, no significant difference; ${ }^{*} p<0.05 ;{ }^{* *} p<0.01$; $* * *<0.001$.

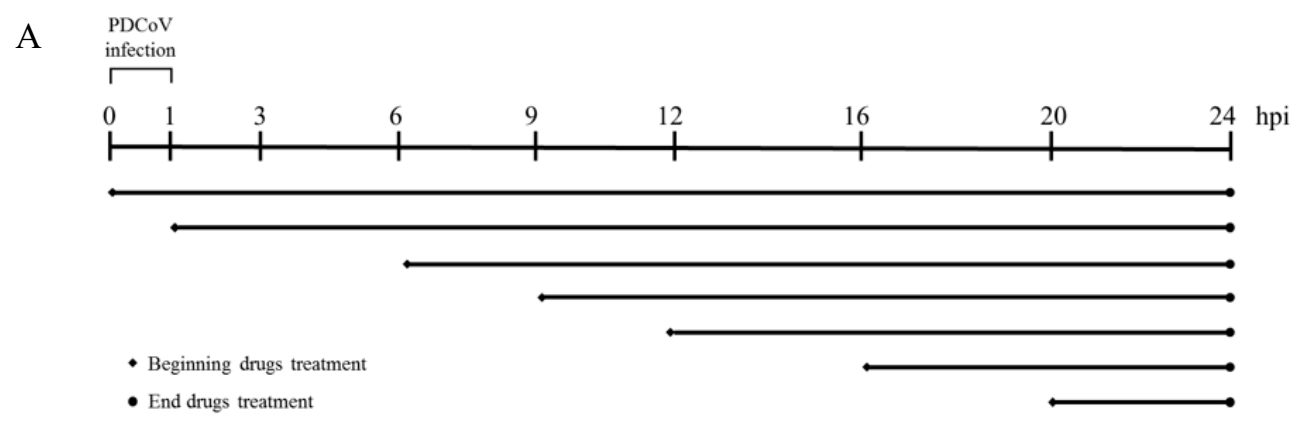

B

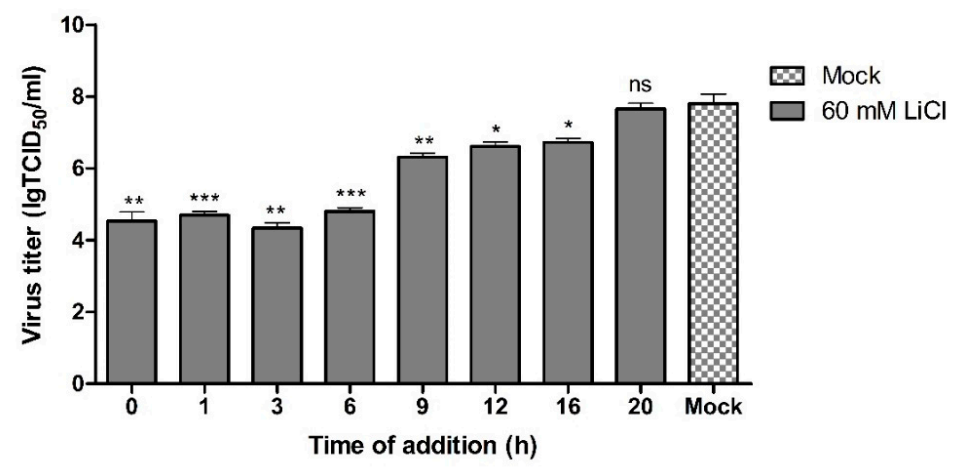

C

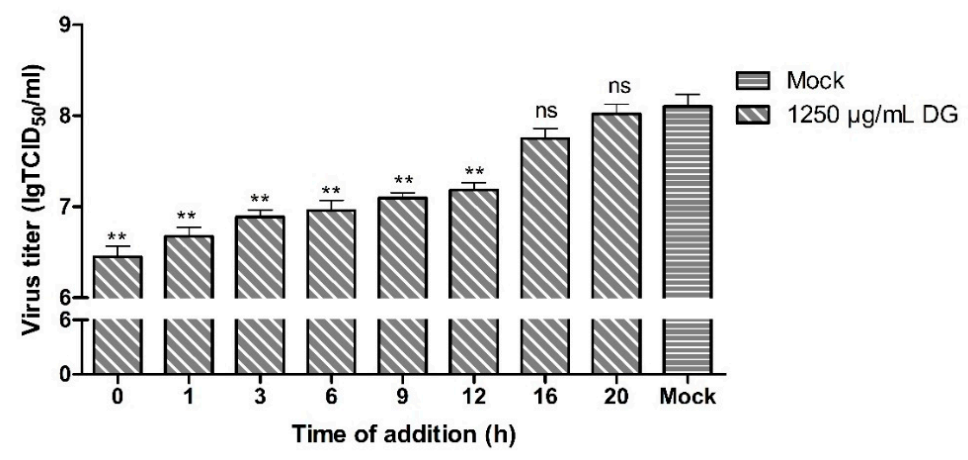

Figure 6. Time-dependent effect of $\mathrm{LiCl}$ and DG on PDCoV replication. (A) Outline of the experimental set up. (B,C) LLC-PK1 cells were incubated with PDCoV (MOI 0.05) for $1 \mathrm{~h}$, followed by treatment with $60 \mathrm{mM} \mathrm{LiCl}$ (B) or $1250 \mu \mathrm{g} / \mathrm{mL} \mathrm{DG} \mathrm{(C)} \mathrm{at} \mathrm{the} \mathrm{indicated} \mathrm{time} \mathrm{(hpi).} \mathrm{The} \mathrm{viral} \mathrm{titer} \mathrm{in} \mathrm{LLC-PK1} \mathrm{cell}$ lysates was calculated using the method of Reed and Muench. Values represent the mean \pm SD of three independent experiments; ns, no significant difference; ${ }^{*} p<0.05 ;{ }^{* *} p<0.01 ;{ }^{* * *} p<0.001$. 
$\mathrm{LiCl}$ and DG inhibit LLC-PK1 apoptosis caused by PDCoV infection. The AnnexinV Alexa Fluor647/PI kit was used to detect cell apoptosis. We found that PDCoV could cause apoptosis within 36 hpi. The percentages of apoptotic cells infected by mock-treated, LiCl-treated viruses, and DG-treated viruses were 30.1\%, 2.3\%, 3.3\%, respectively (Figure 7). Additionally, both drugs presented the same apoptosis-inhibition trend. Therefore, it can be concluded that LiCl and DG can inhibit PK1 cell apoptosis caused by PDCoV infection.
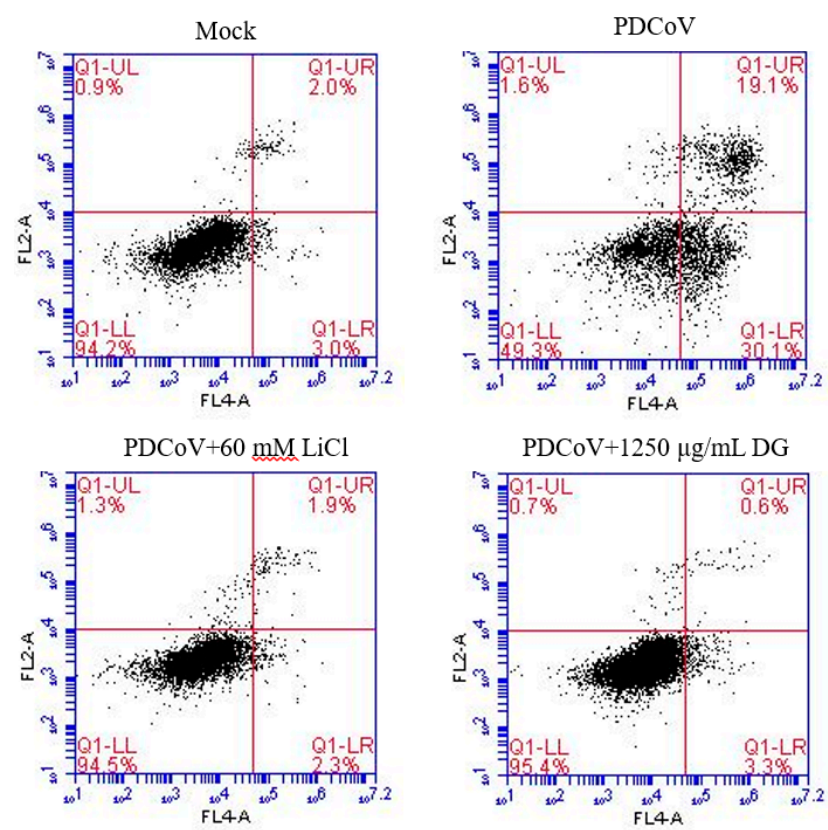

Figure 7. Effect of $\mathrm{LiCl}$ and DG on cell apoptosis caused by PDCoV infection. The cells were incubated with PDCoV (MOI 0.05) for $1 \mathrm{~h}$. Thereafter, the supernatant was removed, and DMEM supplemented with $60 \mathrm{mM} \mathrm{LiCl}$ or $1250 \mu \mathrm{g} / \mathrm{mL}$ DG was added. At $36 \mathrm{hpi}$, the rates of cell apoptosis were analyzed by flow cytometry.

\section{Discussion}

PDCoV infection can cause vomiting and watery diarrhea in piglets and seriously damage the growth of the pig industry. Until now, there are no records of clinically effective agents for the treatment of PDCoV infection, and no compound has shown antiviral activity [35]. Therefore, there is an urgent need to develop a good approach for preventing PDCoV infection. Because neither specific antiviral drugs nor vaccines are available for newly emerging viruses and it is not possible to develop small-molecule drugs and vaccines that act on PDCoV in a short period of time, the novel use of traditional drugs has long been considered to be an important means of finding new therapies targeting new infectious diseases [36]. It has been reported that $\mathrm{LiCl}$ and $\mathrm{DG}$, which are often deemed broad-spectrum antiviral reagents, have antiviral properties against coronaviruses such as SARS-CoV, IBV, and PEDV. However, it remains unknown whether LiCl or DG has an inhibitory effect on PDCoV infection.

In this study, we used real-time $\mathrm{qPCR}, \mathrm{TCID}_{50}$, and IFA to analyze PDCoV infection. Real-time qPCR was used to analyze the level of PDCoV mRNA expression during PDCoV replication. The infectious titer was determined by $\mathrm{TCID}_{50}$, and the fluorescence signals detected by IFA were representative of the level of PDCoV protein expression. We found that $\mathrm{LiCl}$ and DG inhibited the replication of PDCoV in LLC-PK1 cells in a dose-dependent manner. By performing time-of-addition experiments, we aimed to identify the stage of the viral replication cycle targeted by the drugs. We found that both drugs can reduce viral RNA in cell lysates at the early stages of PDCoV replication. 
The viral replication cycle includes attachment, entry, transcription, replication, gene expression, assembly, maturation, and release. We found that DG can inhibit the attachment of the virus to the cell surface, which is consistent with the results of a recent report showing that glycyrrhizin achieved a dose-dependent inhibition of the replication of HIV-1 in MOLT-4 cells, and could interfere with virus-cell binding [37]. However, the specific mechanism needs further investigation. Future experiments will determine if DG can be used not only as a treatment but also for preventing PDCoV infection. Because DG has a good water solubility, it can be used as aerosol disinfectant in piggeries to prevent the outbreak of porcine epidemic diarrhea. According to the antiviral effect, the antiviral activity of $\mathrm{LiCl}$ is better than that of DG, and the toxicity of DG is less than that of $\mathrm{LiCl}$. We investigated the effect of $\mathrm{LiCl}$ combined with DG on the replication of PDCoV in LLC-PK1 cells. There were no significant differences between LiCl-treated cells and cells treated with $\mathrm{LiCl}$ and DG in the mean relative viral mRNA levels, indicating that there is no synergy in the inhibition of viral replication when both drugs are used in combination (data not shown).

We also found that $\mathrm{LiCl}$ and DG could inhibit LLC-PK1 cell apoptosis caused by PDCoV infection similarly to the results of a previous report [28]. Apoptosis is considered a host innate defense mechanism to eliminate virus-infected cells. However, some viruses use and trigger apoptosis to facilitate the release of viral progeny for further dissemination. This can be fundamental for viral pathogenesis and disease development to promote cell death and tissue injury. Previous studies showed that PDCoV induces caspase-dependent apoptosis through the activation of the cytochrome c-mediated intrinsic mitochondrial pathway [38]. Whether LiCl and DG inhibit PDCoV-induced apoptosis through suppression of the cytochrome c-mediated intrinsic mitochondrial pathway needs to be further studied.

In conclusion, our results indicate that $\mathrm{LiCl}$ and DG have potential as effective anti-PDCoV drugs. During an outbreak of porcine epidemic diarrhea, $\mathrm{LiCl}$ and DG could be added to drinking water at the appropriate dose or be given as an intramuscular drug for treatment at the early onset of an epidemic. Further studies are required to explore their antiviral effect against other CoVs and their mechanism of action to control PDCoV infection in vivo.

Author Contributions: Conceived and designed the experiments: X.Z., S.W., S.S. Performed the experiments: X.Z., S.W., M.Z., W.H., Z.P. Analyzed the experiments: X.Z., S.W., S.S. Contributed reagents/Materials: M.Z., W.H., Z.P. Wrote the paper: X.Z., S.W., S.S. All authors read and approved the manuscript.

Funding: This work was financially supported by the National Key Research and Development Program of China (2017YFD0500101), the National Natural Science Foundation of China (31922081), the Natural Science Foundation of Jiangsu Province (BK20170721), the China Association for Science and Technology Youth Talent Lift Project (2017-2019).

Conflicts of Interest: The authors declare no conflict of interest.

\section{References}

1. Marthaler, D.; Lindsey, R.; Yin, J.; James, C.; Kurt, R.; Albert, R. Rapid Detection, Complete Genome Sequencing, and Phylogenetic Analysis of Porcine Deltacoronavirus. Emerg. Infect. Dis. 2014, $20,1347$. [CrossRef] [PubMed]

2. Li, G.; Chen, Q.; Harmon, K.M.; Yoon, K.-J.; Schwartz, K.J.; Hoogland, M.J.; Gauger, P.C.; Main, R.G.; Zhang, J. Full-Length Genome Sequence of Porcine Deltacoronavirus Strain USA/Ia/2014/8734. Genome Announc. 2014, 2, e00278-14. [CrossRef] [PubMed]

3. Woo, P.C.Y.; Lau, S.K.P.; Lam, C.S.F.; Lau, C.C.Y.; Tsang, A.K.L.; Lau, J.H.N.; Bai, R.; Teng, J.L.L.; Tsang, C.C.C.; Wang, M. Discovery of Seven Novel Mammalian and Avian Coronaviruses in the Genus Deltacoronavirus Supports Bat Coronaviruses as the Gene Source of Alphacoronavirus and Betacoronavirus and Avian Coronaviruses as the Gene Source of Gammacoronavirus and Deltacoronavir. J. Virol. 2012, 86, 3995. [CrossRef] [PubMed]

4. Geoghegan, J.L.; Duchãane, S.; Holmes, E.C. Comparative Analysis Estimates the Relative Frequencies of Co-Divergence and Cross-Species Transmission within Viral Families. PLoS Pathog. 2017, 13, e1006215. [CrossRef] [PubMed] 
5. Peiris, J.S.; Lai, S.T.; Poon, L.L.; Guan, Y.; Yam, L.Y.; Lim, W.; Nicholls, J.; Yee, W.K.; Yan, W.W.; Cheung, M.T. Coronavirus as a Possible Cause of Severe Acute Respiratory Syndrome. Lancet 2003, 361, 1319-1325. [CrossRef]

6. Su, S.; Wong, G.; Shi, W.F.; Liu, J.; Lai, A.C.K.; Zhou, J.Y.; Liu, W.J.; Bi, Y.H.; Gao, G.F. Epidemiology, Genetic Recombination, and Pathogenesis of Coronaviruses. Trends Microbiol. 2016, 24, 490-502. [CrossRef] [PubMed]

7. Graham, R.L.; Ralph, S.B. Recombination, Reservoirs, and the Modular Spike: Mechanisms of Coronavirus Cross-Species Transmission. J. Virol. 2010, 84, 3134. [CrossRef] [PubMed]

8. Janetanakit, T.; Lumyai, M.; Bunpapong, N.; Boonyapisitsopa, S.; Chaiyawong, S.; Nonthabenjawan, N.; Kesdaengsakonwut, S.; Amonsin, A. Porcine Deltacoronavirus, Thailand, 2015. Emerg. Infect. Dis. 2016, 22, 757-759. [CrossRef]

9. Liu, S.; Chen, J.; Chen, J.; Kong, X.; Shao, Y.; Han, Z.; Feng, L.; Cai, X.; Gu, S.; Liu, M. Isolation of Avian Infectious Bronchitis Coronavirus from Domestic Peafowl (Pavo Cristatus) and Teal (Anas). J. Gen.Virol. 2005, 86, 719-725. [CrossRef]

10. Wang, L.; Beverly, B.; Yan, Z. Porcine Coronavirus Hku15 Detected in 9 US States, 2014. Emerg. Infect. Dis. 2014, 20, 1594-1595. [CrossRef]

11. Li, W.; Hulswit, R.J.; Kenney, S.P.; Widjaja, I.; Jung, K.; Alhamo, M.A.; Bosch, B.J. Broad Receptor Engagement of an Emerging Global Coronavirus May Potentiate Its Diverse Cross-Species Transmissibility. Proc. Natl. Acad. Sci. USA 2018, 115, 201802879. [CrossRef] [PubMed]

12. Li, W.; Moore, M.J.; Vasilieva, N.; Sui, J.; Wong, S.K.; Berne, M.A.; Choe, H. Angiotensin-Converting Enzyme 2 Is a Functional Receptor for the Sars Coronavirus. Nature 2003, 426, 450-454. [CrossRef]

13. Raj, V.S.; Mou, H.; Smits, S.L.; Dekkers, D.H.; Müller, M.A.; Dijkman, R.; Thiel, V. Dipeptidyl Peptidase 4 Is a Functional Receptor for the Emerging Human Coronavirus-Emc. Nature 2013, 495, 251-254. [CrossRef] [PubMed]

14. Shi, Y.; Wu, Y.; Zhang, W.; Qi, J.; Gao, G.F. Enabling the 'Host Jump': Structural Determinants of Receptor-Binding Specificity in Influenza a Viruses. Nat. Rev. Microbiol. 2014, 12, 822-831. [CrossRef] [PubMed]

15. Lou, Z.; Sun, Y.; Rao, Z. Current Progress in Antiviral Strategies. Trends Pharm. Sci. 2014, 35, 86-102.

16. Kaufmann, S.; Dorhoi, A.; Hotchkiss, R.S.; Bartenschlager, R. Host-Directed Therapies for Bacterial and Viral Infections. Nat. Rev. Drug Discov. 2018, 17, 35. [CrossRef] [PubMed]

17. Martinez, J.P.; Sasse, F.; BrãNstrup, M.; Diez, J.; Meyerhans, A. Antiviral Drug Discovery: Broad-Spectrum Drugs from Nature. Nat. Prod. Rep. 2014, 32, 29-48. [CrossRef] [PubMed]

18. Hoffmann, H.H.; Andrea, K.; Simon, V.A.; Peter, P.; Shaw, M.L. Broad-Spectrum Antiviral That Interferes with De Novo Pyrimidine Biosynthesis. Proc. Natl. Acad. Sci. USA 2011, 108, 5777-5782. [CrossRef] [PubMed]

19. Yang, Y.Q.; Cao, L.; Gao, H.Y.; Wu, Y.; Wang, Y.X.; Fang, F.; Lan, T.L.; Lou, Z.Y.; Rao, Y. Discovery, Optimization, and Target Identification of Novel Potent Broad-Spectrum Antiviral Inhibitors. J. Med. Chem. 2019, 62, 4056-4073. [CrossRef]

20. Adam, M.; Nichol, S.T.; Spiropoulou, C.F. Hantavirus Pulmonary Syndrome. Virus Res. 2011, 162, $138-147$.

21. Lin, Z.F.; Li, Y.H.; Gong, G.F.; Xia, Y.; Wang, C.B.; Chen, Y.; Hua, L.; Zhong, J.Y.; Tang, Y.; Liu, X.M.; et al. Restriction of H1n1 Influenza Virus Infection by Selenium Nanoparticles Loaded with Ribavirin Via Resisting Caspase-3 Apoptotic Pathway. Int. J. Nanomed. 2018, 13, 5787-5797. [CrossRef] [PubMed]

22. Pires de Mello, C.; Drusano, G.; Rodriquez, J.; Kaushik, A.; Brown, A. Antiviral Effects of Clinically-Relevant Interferon-A and Ribavirin Regimens against Dengue Virus in the Hollow Fiber Infection Model (Hfim). Viruses 2018, 10, 317. [CrossRef] [PubMed]

23. Gallegos, K.M.; Drusano, G.L.; D’Argenio, D.Z.; Brown, A.N. Chikungunya Virus: In Vitro Response to Combination Therapy with Ribavirin and Interferon Alfa 2a. J. Infect. Dis. 2016, 214, 1192-1197. [CrossRef] [PubMed]

24. Skinner, G.R.B.; Hartley, C.; Buchan, A.; Harper, L.; Gallimore, P. The Effect of Lithium Chloride on the Replication Ofherpes Simplex Virus. Med. Microbiol. Immunol. 1980, 168, 139-148. [CrossRef] [PubMed]

25. Ren, X.; Fandan, M.; Jiechao, Y.; Guangxing, L.; Xunliang, L.; Chao, W.; Georg, H. Action Mechanisms of Lithium Chloride on Cell Infection by Transmissible Gastroenteritis Coronavirus. PLoS ONE 2011, 6, e18669. [CrossRef] [PubMed] 
26. Ping, H.H.; Wen, L.B.; Li, J.R.; Wang, Y.; Ni, B.; Wang, R.; Wang, X.; Sun, M.X.; Fan, H.J.; Mao, X. Licl Inhibits Prrsv Infection by Enhancing Wnt/B-Catenin Pathway and Suppressing Inflammatory Responses. Antiviral Res. 2015, 117, 99-109.

27. Xiuwen, S.; Yin, J.; Ren, X. Antiviral Effect of Diammonium Glycyrrhizinate and Lithium Chloride on Cell Infection by Pseudorabies Herpesvirus. Antiviral Res. 2010, 85, 346-353.

28. Jie, L.H.; Gao, D.S.; Li, Y.T.; Wang, Y.S.; Liu, H.Y.; Zhao, J. Antiviral Effect of Lithium Chloride on Porcine Epidemic Diarrhea Virus in Vitro. Res. Vet. Sci. 2018, 118, 288-294.

29. Wang, Z.W.; Sun, N.; Wu, C.H.; Jiang, J.B.; Bai, Y.S.; Li, H.Q. In Vitro Antiviral Activity and Underlying Molecular Mechanisms of Dipotassium Glycyrrhetate against Porcine Reproductive and Respiratory Syndrome Virus. Antiviral Ther. 2013, 18, 997-1004. [CrossRef] [PubMed]

30. Sasaki, H.; Takei, M.; Kobayashi, M.; Pollard, R.B.; Suzuki, F. Effect of Glycyrrhizin, an Active Component of Licorice Roots, on Hiv Replication in Cultures of Peripheral Blood Mononuclear Cells from Hiv-Seropositive Patients. Pathobiology 2003, 70, 229-236. [CrossRef] [PubMed]

31. Hitoshi, S.; Goto, W.; Yamamura, J.I.; Kurokawa, M.; Kageyama, S.; Takahara, T.; Watanabe, A.; Shiraki, K. Therapeutic Basis of Glycyrrhizin on Chronic Hepatitis B. Antiviral Res. 1996, 30, 171-177.

32. Marc, C.J.; Biziagos, E.; Jouan, A.; Deloince, R. Studies on Mechanism of Action of Glycyrrhizin against Hepatitis a Virus Replication in Vitro. Antiviral Res. 1994, 23, 63-76.

33. Cinatl, J.; Morgenstern, B.; Bauer, G.; Chandra, P.; Rabenau, H.; Doerr, H.W. Glycyrrhizin, an Active Component of Liquorice Roots, and Replication of Sars-Associated Coronavirus. Lancet 2003, 361, $2045-2046$. [CrossRef]

34. Li, J.; Yin, J.; Sui, X.; Li, G.; Ren, X. Comparative Analysis of the Effect of Glycyrrhizin Diammonium and Lithium Chloride on Infectious Bronchitis Virus Infection in Vitro. Avian Pathol. 2009, 38, 215-221. [CrossRef] [PubMed]

35. Wang, B.; Liu, Y.; Ji, C.M.; Yang, Y.L.; Liang, Q.Z.; Zhao, P.; Xu, L.D.; Lei, X.M.; Luo, W.T.; Qin, P.; et al. Porcine Deltacoronavirus Engages the Transmissible Gastroenteritis Virus Functional Receptor Porcine Aminopeptidase N for Infectious Cellular Entry. J. Virol. 2018, 92, JVI003-18.

36. De Clercq, E.; Li, G. Approved Antiviral Drugs over the Past 50 Years. Clin. Microbiol. Rev. 2016, $29,695$. [CrossRef]

37. Masahiko, I.; Sato, A.; Hirabayashi, K.; Tanabe, F.; Shigeta, S.; Baba, M.; de Clercq, E.; Nakashima, H.; Yamamoto, N. Mechanism of Inhibitory Effect of Glycyrrhizin on Replication of Human Immunodeficiency Virus (Hiv). Antiviral Res. 1988, 10, 289-298.

38. Lee, Y.J.; Lee, C. Porcine Deltacoronavirus Induces Caspase-Dependent Apoptosis through Activation of the Cytochrome C-Mediated Intrinsic Mitochondrial Pathway. Virus Res. 2018, 253, 112-123. [CrossRef] 